PREVALENCE OF BOVINE FASCIOLOSIS AT THE IBADAN MUNICIPAL ABATTOIR, NIGERIA

\title{
Oladele-Bukola $\mathrm{MO}^{1}$ and IA Odetokun ${ }^{2}$
}

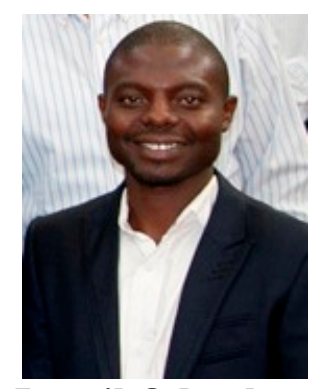

Ismail Odetokun

*Corresponding author’s email: ismail23us@yahoo.com

${ }^{1}$ Institute of Agricultural Research and Training (IAR\&T), Ibadan, Nigeria

${ }^{2}$ Department of Veterinary Public Health and Preventive Medicine, University of Ibadan Ibadan, Nigeria. 


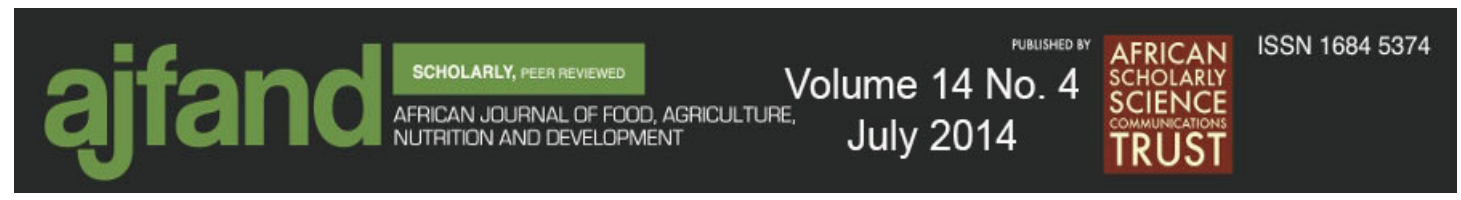

\section{ABSTRACT}

Food animals are important sources of high quality protein and revenue to man, and can also serve as vehicles for disease transmission. Apart from economic losses, diseased organs in slaughtered cattle can also be sources of epidemiologic and zoonotic threats to man if not detected and controlled. The study was conducted to evaluate the number of cattle slaughtered, prevalence, seasonal variation, and socioeconomic consequence of bovine fasciolosis at the Ibadan Municipal abattoir, Ibadan, Oyo State, Nigeria, between 1994 and 2004 based on retrospective abattoir meat inspection records and a perspective meat inspection survey. Of the 1, 640,095 cattle slaughtered in 11 years, 37, 828 livers were condemned due to fasciolosis, translating into a prevalence of $2.31 \%$. The incidence observed among males 172 (4.24\%) was slightly higher than noted for females 452 (3.73\%) though significant at 0.05 level of error. More so, the prevalence recorded in the dry season (October - March) was 19, $816(2.58 \%)$ and 18, $012(2.07 \%)$ for the rainy season (April - September) with a fairly strong positive correlation $(+0.76)$ occurring between the incidence of the disease in the seasons. The economic impact of the losses due to fasciolosis was estimated at $\$ 19,618,639$ Nigerian Naira $(\$ 147,121)$ which was a huge loss to the livestock industry and the nation . With these findings, there is need to carry out a more elaborate survey of the disease in selected abattoirs, clinical and parasitological surveys in ranches and ecological studies in majors rivers and ponds throughout the country. Public awareness campaigns, planned herd health programmes, flukes and intermediate hosts control and effective meat inspection are also needed. There should be enforcement of ante-mortem examination in all abattoirs in Nigeria in order to reduce wastage while identifying diseases of public health and economic importance before slaughter. This will minimize health risks and the associated huge economic loss. Compensation of butchers and meat traders with condemned livers is recommended, in order to salvage constant prevalence of fasciolosis in Nigeria.

Key words: Fasciolosis, Cattle, Prevalence, Abattoir, Nigeria 


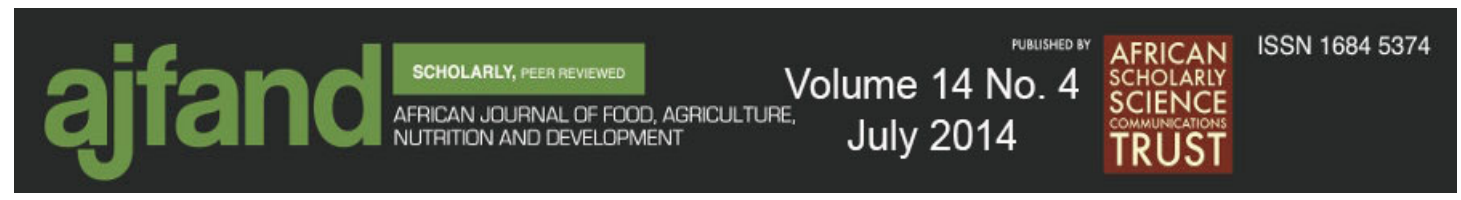

\section{INTRODUCTION}

Slaughter houses provide an excellent opportunity for detecting diseases of both economic and public health importance. It is necessary to know the extent to which the public is exposed to zoonotic diseases as observed in abattoirs [1]. Meat is a perishable commodity, and poor handling daily can exert both public health and economic toll on any nation, and there should be no room for complacency over problems of meat hygiene, either in developed or in the developing countries [2]. Bovine fasciolosis is a parasitic disease of cattle caused by trematodes usually Fasciola gigantic and rarely Fasciola hepatica in the tropics. The life cycle of these trematodes involves snail as an intermediate host [3]. The disease (Fasciolosis) is usually characterized by a chronic, sometimes acute or sub-acute inflammation of the liver and bile ducts, accompanied by sub-mandibular oedema, anaemia, anorexia, general intoxication and death [4]. Meats infected by this organism are regularly condemned at inspection in abattoirs/slaughter slabs. It could be zoonotic while constituting a major economic problem by lowering the productivity of cattle, in addition to losses from condemnation of affected organs. Humans can accidentally ingest the eggs/larvae and become infected [5]. Fasciolosis is enzootic in Nigeria and is of great economic importance especially in northern Nigeria where stagnant water and 'fadamas' are used as watering and grazing sites in the dry season.

Important economic losses associated with fasciolosis are: great expenses on anthelmintics for treatment; liver condemnation; production loss due to mortality; lower production of meat, milk and wool; reduced weight gain; metabolic diseases and impaired fertility [6,7]. The value of the losses resulting from this disease runs into millions of naira [4]. However, the estimation of economic losses due to fasciolosis at national and regional level is limited by lack of accurate estimation of prevalence of the disease [8]. Apart from direct economic losses associated with the disease, other non-quantifiable losses are also experienced. For instance, liver is generally regarded as a delicacy in Nigeria, usually in high demand. This makes condemnation during post-mortem inspection a problem as butchers and meat traders hide their meats from inspectors or even refuse inspection. Others are: death of unknown number of animals (including the under-aged) due to acute fasciolosis; indirect losses from the chronic form of the disease e.g. poor feed conversion, weight loss, slow fattening, reduced milk yield, and ultimately death. Also, it leads to an additional cost of control in terms of medication costs, veterinary fees, and labour costs aimed at reducing parasitism.

Cases of human fasciolosis are said to be on the increase since the 1980's. Apart from its veterinary and economic importance throughout the world, fasciolosis has recently been shown to be a re-emerging and widespread zoonosis, affecting many people [9]. Any observation and information obtained at slaughterhouse can contribute to the understanding of slaughtered animals' diseases [1]. Data collected from the abattoir can be used in tracing back in order to detect disease outbreaks and plan control programmes, and indeed, such processes have been used to determine the prevalence of infectious and parasitic diseases in the past in Nigeria [2]. This study, therefore, 


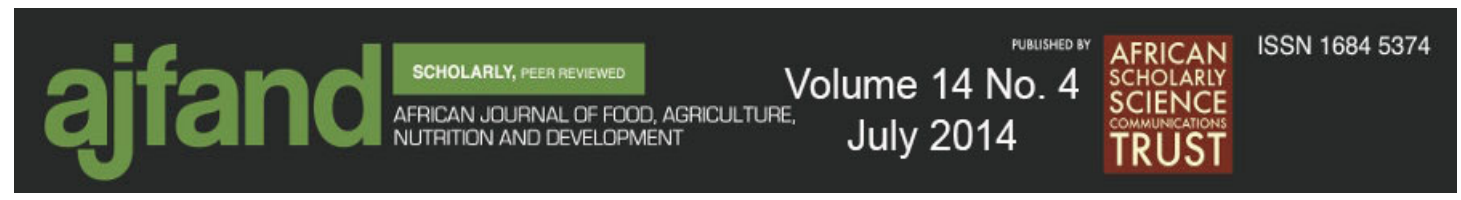

would serve to recognize and appreciate the magnitude of problems and losses posed by fasciolosis. It will fill knowledge gaps and update existing information on bovine fasciolosis in Nigeria. This will serve as additional reference information on the losses from condemned liver (due to fasciolosis), which is not readily available in the literature. This will eventually stimulate the interest to intensify efforts on its monitoring and surveillance towards the control and possible eradication of the disease in Nigeria.

\section{MATERIALS AND METHODS}

\section{The Study Area}

The Ibadan Municipal Abattoir selected for this study is located in Ibadan city, the capital of Oyo State within the Southwestern geopolitical zone of Nigeria. Ibadan city, with a dense population of 1,338,659 according to the 2006 census [10], is one of biggest cities in sub-Sahara Africa. It is located on a grid reference longitude $3^{0} 5 \mathrm{E}$ and latitude $7^{0} 20 \mathrm{~N}$ [11]. The city ranges in elevation from 150 to $275 \mathrm{~m}$ above sea level and has an annual precipitation of 1,121 (44.13) mm (inches).

\section{Data Collection}

This was done in stages. First, a retrospective data covering eleven years (1994-2004) was obtained from the Disease Monitoring Unit of the Veterinary Department, Ministry of Agriculture and Natural Resources (MANR), Ibadan, Oyo State, Nigeria. Records of number of cattle slaughtered (including sex), liver condemnation (partial or total), reasons for such condemnations and the prevailing prices of meat and offals were noted. In the second stage (perspective study), meat inspection and recording of all cases of bovine fasciolosis for a period of four months (September-December, 2004) was carried out. This is to determine the presence and intensity of bovine fasciolosis (including sex differences) at slaughter so that a need for routine monitoring and surveillance of the parasite could be proposed [12]. Post-mortem examination was carried out by visual inspection, palpation, incision and olfaction. The breeds of cattle (Bos indicus) inspected include White Fulani (Bunaji), Red Bororo, Keteku, Muturu, Ndama and Sokoto Gudali. Prices of meat and offals were determined through interviews periodically conducted with cattle traders at the Bodija livestock market (where Ibadan Municipal Abattoir is located) at different periods.

\section{Data Analysis}

Data on the total number of cattle slaughtered, sex and cases of fasciolosis collected on a daily basis from 1994 to 2004 were used. The statistical analysis on bovine fasciolosis was computed on the number of cases of fasciolosis determined at postmortem inspection to the total number of cattle slaughtered expressed in percentage [13], for the years under review. Also, the incidence of fasciolosis in cattle examined during the abattoir survey between September and December 2004 was determined as well as sex differences statistically tested using chi-square test at $95 \%$ level of significance and value of $\mathrm{p}<0.05$ were considered significant [14]. The seasonal variation in the pattern of occurrence over the years was analyzed using the Pearson's 


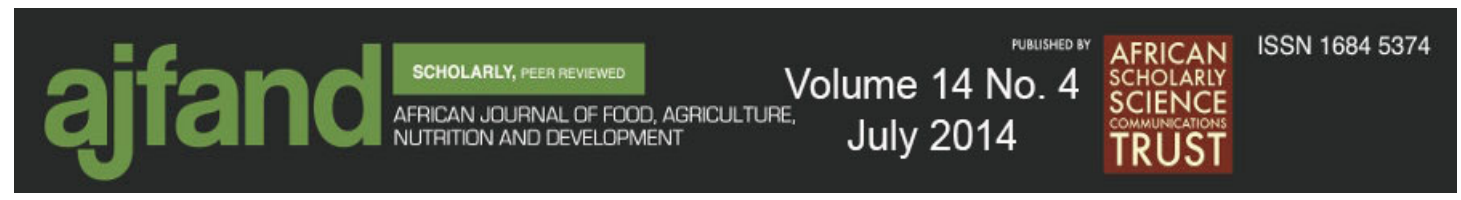

Product Moment Correlation. The results were analyzed to determine the prevalence of bovine fasciolosis.

The direct economic losses from the condemned bovine liver expressed in Naira (Nigerian currency) were analyzed using the formula adopted from Bekele et al. [15]:

$\mathrm{EL}=\sum \mathrm{CS} \times \mathrm{Coy} \times \mathrm{Roz}$

Where:

EL - Annual loss estimated due to liver condemnation

$\sum$ CS - annual slaughter rates at the abattoir (estimated from retrospective abattoir record)

Coy - Average cost of each cattle liver

Roz - Condemnation rates of cattle liver due to fasciolosis

The values in Naira were converted to US dollars using the Central Bank of Nigeria's [16] Inter-bank Foreign Exchange Market rate of 2004 ( \$1 = 133.35$).$

\section{RESULTS}

A total of 1,640,095 cattle were slaughtered between January 1994 and December, 2004 with an average of 12, 425 per month (Table 1). During the same period, a total of 762,118 (46.5\%) cows and 877,977 (53.5\%) bulls were slaughtered with averages of 69,283 cows and 79,816 bulls per annum, respectively. The abattoir record showed that a total of 37,828 (2.31\%) of slaughtered cattle were infected with bovine fasciolosis. The annual infection rates ranged from $1.57 \%$ to $5.68 \%$ with a mean of $3.7 \%$. Generally, there was a reasonable declination in the prevalence of fasciolosis detected across the years 1994-2004.

The incidence of fasciolosis in cattle examined after slaughter during the survey at the abattoir between September and December 2004 is shown in Fig.1. Cows had a lower infection rate 452 (3.73\%) than bulls 172 (4.24\%) which was significant at $p<0.05$. An incidence of 624 (3.86\%) was obtained for this period. In both sexes, it decreased across the months. Incidence of fasciolosis ranged from 323 (8.18\%) in September to 77 (1.97\%) in November before it later increased to 90 (3.8\%) in December. 

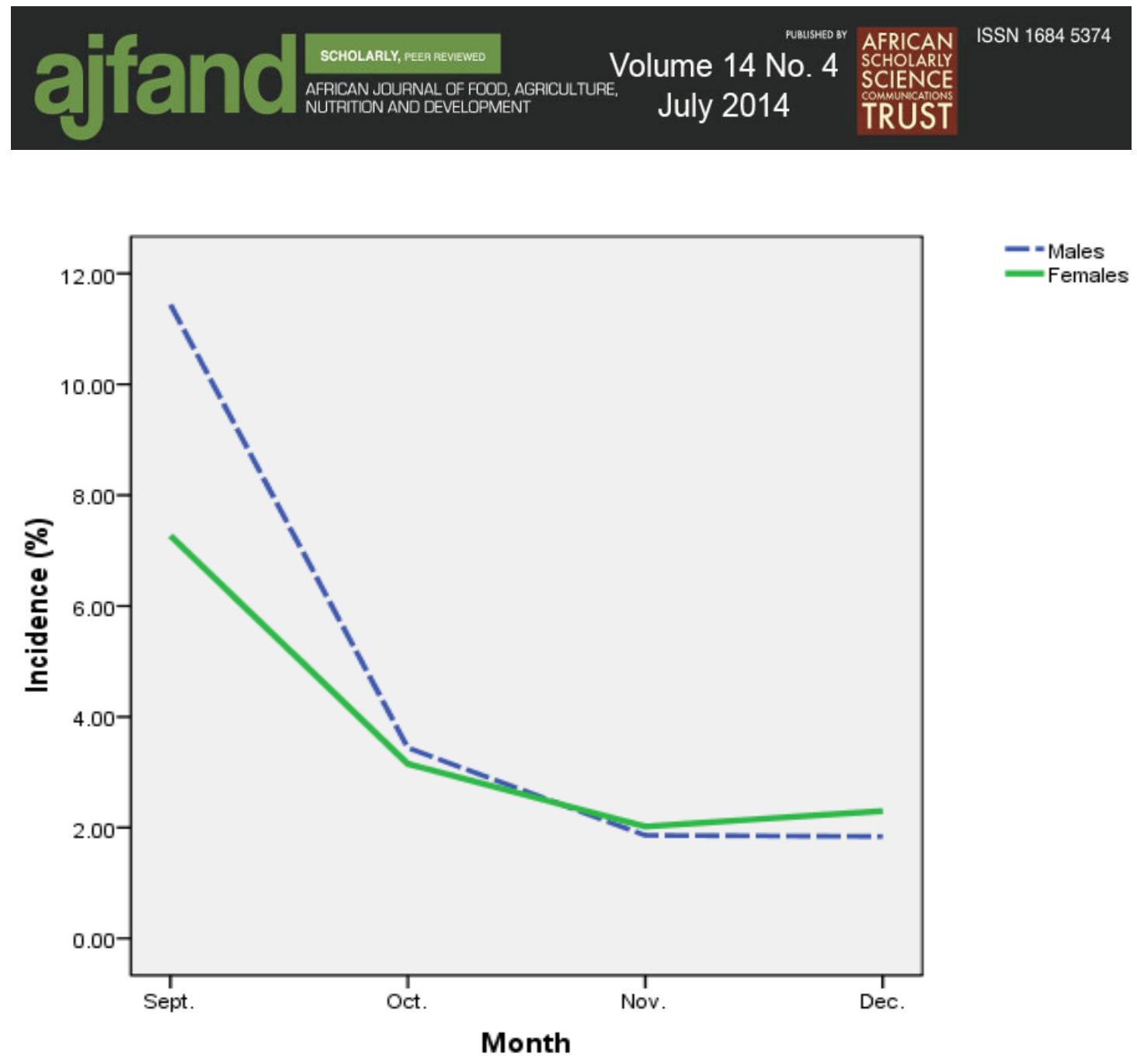

Figure1: Sex variation of bovine fasciolosis surveyed at the Ibadan Municipal Abattoir (Sept. - Dec. 2004)

The uniform reduction in the general prevalence of bovine fasciolosis over the years was characterized by few peaks between 1999 and 2001 (Fig. 2). In the rainy seasons, the consistent decrease was marked with slight surge in 1999 \{1,826 (3.48\%)\} and $2001\{2,558(4.29 \%)\}$, while that of the dry seasons was more cyclical as some elevations in $1995\{1,041$ (5.20\%)\}, $1999\{1,959$ (3.00\%)\} and 2002 \{1,940 (6.05\%) \} were identified. Averagely, higher prevalence was noticed in the dry seasons 19, $816(2.58 \%)$ than for the rainy seasons $\{18,012(2.07 \%)\}$. Notably, a low prevalence of 1,665 (1.03\%) in 1997 was recorded in the dry season while the highest $\{1,099(7.35 \%)\}$ was attained in 1994 during the rainy season. With the Pearson Product Moment Correlation, a fairly strong positive correlation $(+0.76)$ was obtained between the prevalence of the disease in the dry and rainy seasons. 

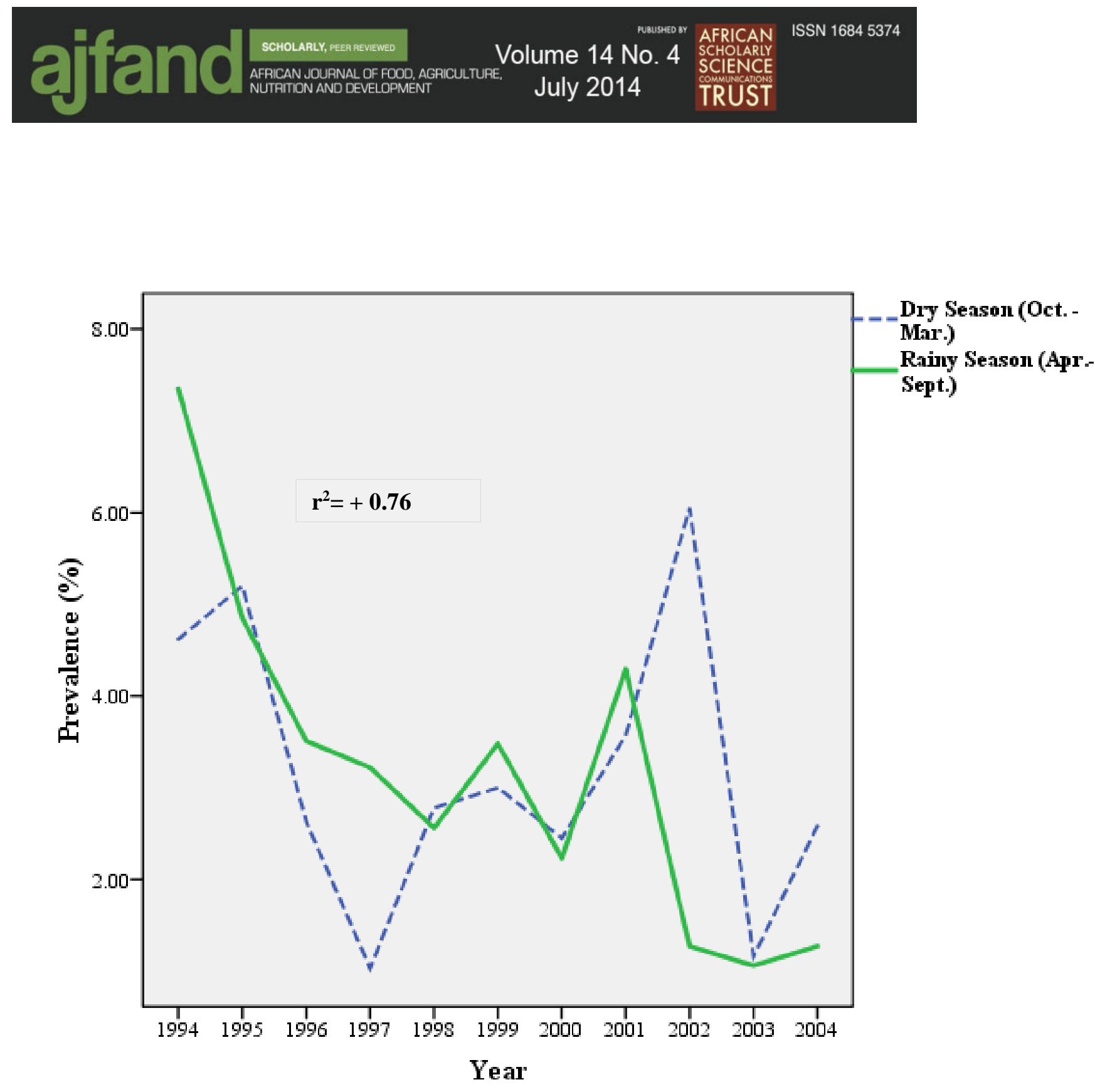

Figure 2: Seasonal variation in the prevalence of bovine fasciolosis at the Ibadan Municipal Abattoir (1994 - 2004).

On economic considerations, the total number of bovine liver condemned per year and degree of condemnation of such livers were observed and recorded during this study. The prices per kg of liver and its associated monetary losses were summarized in Table 2. 160,446,972 cattle were produced nationally from 1994 to 2004 out of which 1,640,095 (1.02\%) were slaughtered at the Ibadan abattoir with 37,828 found to be infected with fasciolosis. The overall financial loss was estimated at $¥ 19$, $618,639.40$ (\$147, 121.41) accruing from a total of $75,644 \mathrm{Kg}$ liver condemned. The highest monetary loss was recorded in 2004 (\$3, 865,725.00/\$28,989.31) with the lowest loss obtained in 1994 (\$698, 744.00/\$5,239.93). $\$ 1,783,512.67$ (\$13,374.67) on the average was incurred as an annual monetary loss due to the disease. 


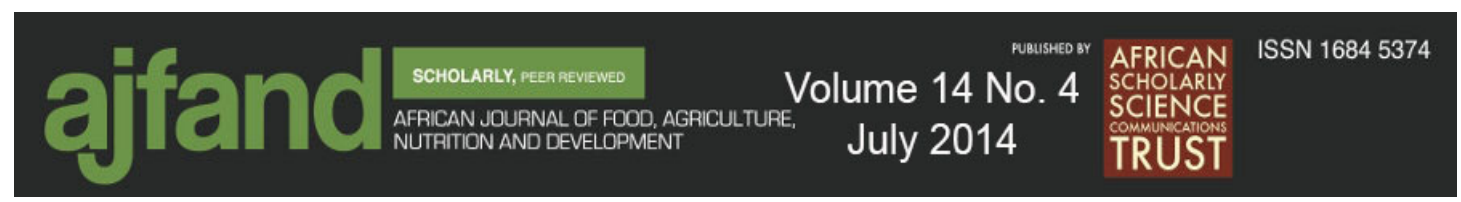

\section{DISCUSSION}

A continuous increase in the number of cattle slaughtered yearly, a low periodic prevalence of bovine fasciolosis determined through meat inspection and liver condemnation, seasonal variation in the prevalence as well as sex variation in the incidence and lastly, a huge economic loss as a result of the disease from January 1994 to December 2004. The growth rate in the National herd is estimated at $1.5 \%$ annually. Increase in number of cattle slaughtered at Ibadan is attributed to the increased population of consumers, purchasing power and a consequent increase in demand for cattle meat over the years. Also, meat commands a much higher premium in the commercial centres of the southern part of Nigeria such as Lagos, Port Harcourt, Enugu, Ibadan do not use etc in the text Consequently, more animals, especially males with good body condition, are transported to these cities with higher population densities where they command a higher price. In cattle markets in northern Nigeria, trucks are always seen loading animals to the southern part of the country [2]. Higher numbers of bulls were slaughtered every year as compared to cows, which indicates consumers' preference for meat from bulls. Cattle rearers prefer to withhold the females for breeding purpose. More cattle were slaughtered in the rainy seasons compared to the dry, possibly due to the usual increase in the numbers of cattle with a corresponding decrease in prices in the rainy seasons especially during festive periods.

The low periodic prevalence of $2.31 \%$ obtained in this study is slightly in consonance with the $2.5 \%$ (mean annual prevalence) stipulated by Ogunrinade and Ogunrinade [4]. Ibironke [17], in Lagos (southwestern Nigeria) recorded a significantly lower prevalence of $0.72 \%$ for bovine fasciolosis in a four-year retrospective study. Available recent reports on the prevalence of bovine fasciolosis from northern Nigeria revealed higher rates. Raji et al. [1] and Alawa et al. [2] recorded $23.41 \%$ and $13.09 \%$, respectively in studies conducted in Zaria, northwestern Nigeria. Additionally, it was 20.95\% [18] in northeastern Nigeria. These higher rates arose because most cattle farmers in the north engage in extensive farming systems with little or no veterinary input. Poor uncoordinated effort in the control of the diseases is another contributory factor coupled with the high cost of drugs against fasciolosis. Self-medication by livestock rearers, possible development of resistance to commonly used anti-fasciola drugs and watering of cattle herds with snail infested water, owing to water scarcity, are other reasons. Also, farmers usually fail to schedule strategic deworming programmes for their animals. All these account for the high incidence of fasciolosis in the bovine liver at slaughter [17]. Bovine fasciolosis is enzootic in Nigeria and a leading cause of condemnation in most abattoirs. It certainly calls for improved control and preventive measure such as regular deworming and avoidance of fadama area for grazing [1]. Probably because there is a gradual increase in the level of awareness on the need to control the disease, the prevalence continued to decline across the years. 


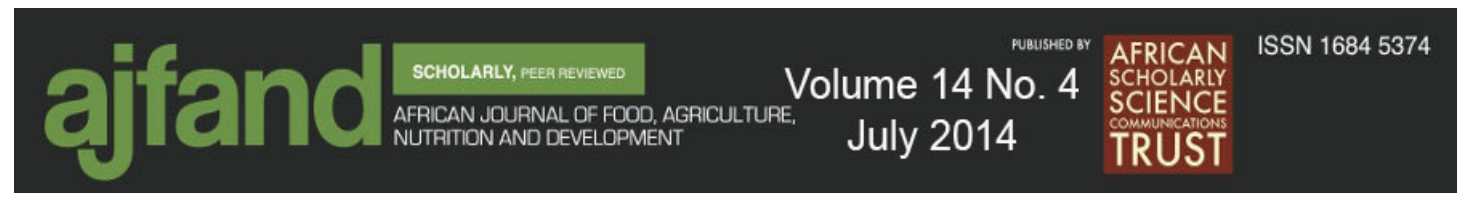

The incidence of 16, 177 (3.86\%) obtained from the survey conducted between September and December 2004 is lower than described in Southeastern Nigeria where infection rates of $7.0 \%, 7.7 \%, 10.8 \%$ and $13.4 \%$ were obtained from four different abattoirs between November and December, 2004 [12]. These higher rates might have been influenced by the period (dry season) in which the survey was carried out. Infection rate among males was higher than in females and statistically significant at $\mathrm{p}$ $<0.05$, similarly as observed by Elkannah [18] but in contrast to some other findings $[5,8]$. Cattle owners rear cows for longer periods because they reproduce and produce milk, unlike bulls. This longer stay makes them more exposed and susceptible to parasitic diseases like fasciolosis. Number of males usually presented at slaughter is higher because they generate higher value for the cattle rearers/sellers than females. In 2004, the average price of a bull in Nigeria was N35, 000 while that of a cow was N30, 000 [19]. Older cows have lower dressing weights and harder meats, requiring long cooking time. These generate low interest from consumers and force down prices of cows. The disparity in susceptibility to helminth infection between the two sexes was attributed to differences in host intrinsic factors (genetics, physiology and immunology) and extrinsic factors (environment and management practices) [8].

Seasonal prevalence of fasciolosis reported during the dry season was averagely higher than observed in the rainy season. Ogunrinade et al. [20] equally recorded related findings. There is a great intensity of final host animals around the drinking sites during the dry seasons and due to the absence of natural pastures, animals were forced to graze Fasciola encysted cercariae contaminated plants around the canal banks [21]. Besides, Fulani nomadic herdsmen are customarily observed to move their cattle down south during the dry season in search of green pastures and water. This makes it possible for the cattle to ingest infective larva of Fasciola on the available pasture during their movement. These transported animals typically end up in cattle markets in the south. In Nigeria, there are no mechanisms in place to ensure that safe, clean and snail free water is provided for cattle especially during the dry season. Adedokun et al. [8], however, discovered higher prevalence in the rainy season (52.3\%) than dry (21\%) though this detection was from cattle faeces. The seasonal incidence of $F$. gigantica was highest during and directly after the rainy season [22]. It was also stated that monthly incidence of fasciolosis was highest during the periods immediately before and after the onset of the rains [23]. Despite the fact that there was consistent reduction in the general prevalence over the years, it is characterized by peaks noted in both seasons with that of the dry season being higher in some years. It is likely that conditions promoting the proliferation of fasciola were more during those years, thus heightening the already constant presence of fasciola, which subsequently led to the sporadic occurrences of fasciolosis as noticed in the years with peaks.

Nigerian livestock sector generates around 5\% of the Nigeria's GDP and about a quarter of total agricultural output [24]. In 2004, the national GDP was \$114.8 billion [25]. The average annual loss of $\$ 1,783,512.63$ (\$13,374.67) and a total periodic loss of $\$ 19,618,639.40$ ( $\$ 147,121.41$ ) resulting from condemnation of 37,828 liver due to fasciolosis out of 1,640,095 cattle slaughtered from 1994 to 2004 were quite 


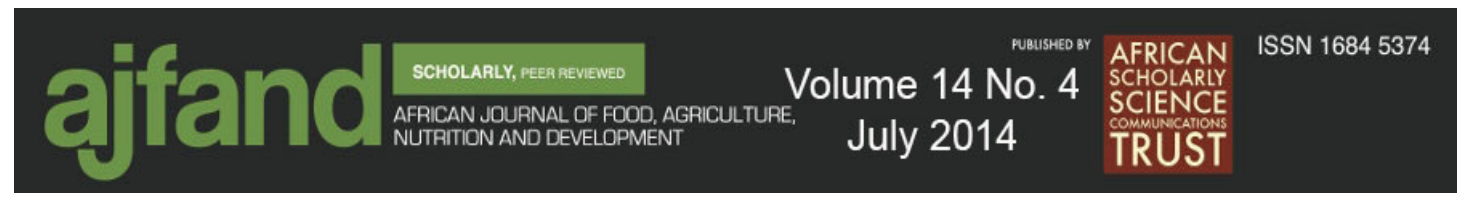

enormous. These highlighted the economic upsets imposed by this disease in the state and the country at large. It is a potential constraint to livestock production in the face of increasing demand for animal protein and has been part of the leading factors contributing to the slow growth of this sector ( $2 \%$ per year), slower than the rest of the economy. Moreover, this economic loss could still be referred to as an underestimation of the actual cost suffered as a result of fasciolosis because of the unavailability of costs due to mortality, chronic ill effect and treatment. Butchers and meat traders resisting inspection of fasciola infested livers is also a contributory factor. This results from the low literacy and awareness levels as well as the increased poverty among abattoir workers coupled with the general public perception that fasciolosis infested livers are treated as delicacies in the Nigeria. Ogunrinade and Ogunrinade [4] reported an annual economic loss of some $\$ 5$ million (US\$37, 495.31). Bovine fasciolosis in Maiduguri resulted in $\$ 188,804.00$ (\$1, 415.85) loss in six years [5]. With an estimated $20 \%$ contribution to national income and $78 \%$ of national meat supply, the Nigerian livestock subsector is obviously a significant source of national wealth and nutrition as well as poverty reduction [24], which should not be allowed to be affected by the colossal economic losses emanating from fasciolosis.

\section{CONCLUSION}

In this study, bovine fasciolosis has been confirmed to be prevalent with higher occurrence in the dry season. This further accentuates that the public is at risk. The high economic loss noted was also significant. Definitely, bovine fasciolosis is responsible for increased production losses in cattle, reduced meat production and a high cost of treatment. Therefore, the results of this study are of utmost importance in the control of bovine fasciolosis in Nigeria.

\section{RECOMMENDATIONS}

It is recommend that bovine fasciolosis be recognized as a serious problem. There is need to carry out a more elaborate survey in all abattoirs, clinical and parasitological surveys in ranches and ecological studies in major rivers and ponds throughout the country. Geographic Information System forecast model should be developed to assess the risk of Fasciola gigantica in Nigeria. This would enable the country to have a better idea of the disease epidemiology and make decision on itscontrol considering local settings. Public awareness campaigns should be embarked upon to enlighten the populace on the ills of fasciolosis. Planned national herd health programmes should be adopted and properly executed. Flukes and intermediate hosts control (integrated vector control), feed supplementation and provision of clean water to cattle especially in the dry season are other recommended control practices. Effective meat inspection and compensation of butchers and meat traders (whose liver are condemned) should be upheld. All these approaches will provide a long-lasting solution to the problem of bovine fasciolosis. 


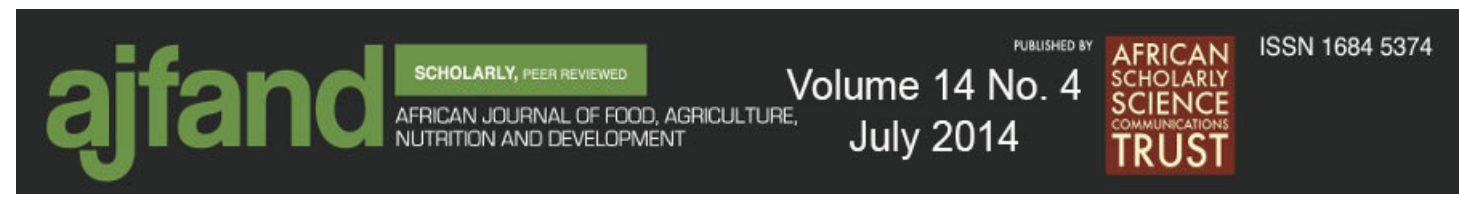

\section{ACKNOWLEDGEMENTS}

The authors would like to acknowledge members of staff of the Disease Monitoring Unit of the Veterinary Department, Ministry of Agriculture and Natural Resources (MANR), Ibadan, Oyo State, Nigeria attached to the Ibadan Municipal abattoir for providing data used in this research and for their cooperation during the perspective survey. 


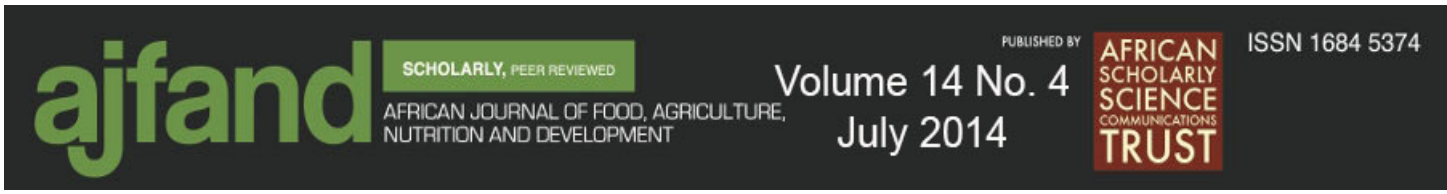

Table 1: Total number of cases of bovine fasciolosis at Ibadan Municipal Abattoir (1994-2004)

\begin{tabular}{lccccc}
\hline Year & $\begin{array}{c}\text { Number of } \\
\text { cattle } \\
\text { slaughtered }\end{array}$ & $\begin{array}{c}\text { Number of } \\
\text { bulls } \\
\text { slaughtered }\end{array}$ & $\begin{array}{c}\text { Number of } \\
\text { cows } \\
\text { slaughtered }\end{array}$ & $\begin{array}{c}\text { Cases of } \\
\text { fasciolosis }\end{array}$ & $\begin{array}{c}\text { Prevalence } \\
\text { (\%) }\end{array}$ \\
\hline 1994 & 38,501 & 22,118 & 16,383 & 2,188 & 5.68 \\
1995 & 43,168 & 26,128 & 17,040 & 2,163 & 5.01 \\
1996 & 104,614 & 55,893 & 48,721 & 3,202 & 3.06 \\
1997 & 118,837 & 56,349 & 62,488 & 5,339 & 2.98 \\
1998 & 119,719 & 58,160 & 61,559 & 3,155 & 2.64 \\
1999 & 117,615 & 63,844 & 53,771 & 3,669 & 3.12 \\
2000 & 199,355 & 56,921 & 62,414 & 2,776 & 3.18 \\
2001 & 122,219 & 59,622 & 62,597 & 4,341 & 3.55 \\
2002 & 261,305 & 208,588 & 52,717 & 4,111 & 1.57 \\
2003 & 310,112 & 147,976 & 162,136 & 3,395 & 1.09 \\
2004 & 284,670 & 122,378 & 162,292 & 5,289 & 1.86 \\
Total & $1,640,095$ & 877,977 & 762,118 & 37,828 & 2.31 \\
Mean $(\chi)$ & 149,099 & 79,816 & 69,283 & 3,439 & \\
\hline
\end{tabular}




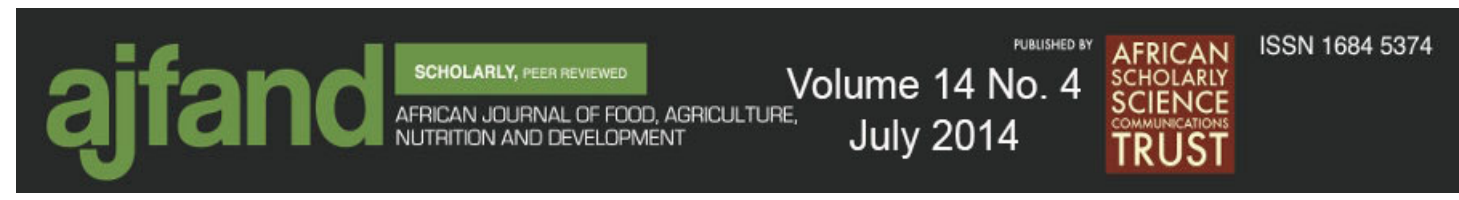

Table 2: Monetary losses resulting from bovine fasciolosis in cattle slaughtered in Ibadan Municipal Abattoir, Ibadan (1994-2004)

\begin{tabular}{|c|c|c|c|c|c|c|}
\hline \multirow[t]{2}{*}{ Year } & \multirow{2}{*}{$\begin{array}{c}\text { National } \\
\text { Cattle } \\
\text { Population* }\end{array}$} & \multirow{2}{*}{$\begin{array}{l}\text { Price } / \mathrm{Kg} \\
\text { of Liver } \\
\text { (\#) }\end{array}$} & \multicolumn{2}{|c|}{$\begin{array}{l}\text { Partially condemned liver } \\
\text { (average weight }=1.4 \mathrm{Kg} \text { ) }\end{array}$} & \multicolumn{2}{|c|}{$\begin{array}{l}\text { Totally condemned livers } \\
\text { (average weight }=3.8 \mathrm{Kg} \text { ) }\end{array}$} \\
\hline & & & $\begin{array}{l}\text { Number of } \\
\text { condemned } \\
\text { liver }\end{array}$ & $\begin{array}{c}\text { Monetary loss } \\
\text { (\#) }\end{array}$ & $\begin{array}{c}\text { Number of } \\
\text { condemned } \\
\text { liver }\end{array}$ & $\begin{array}{c}\text { Monetary } \\
\text { loss (®) }\end{array}$ \\
\hline 1994 & $14,513,300$ & 190 & 1, 932 & $513,912.00$ & 256 & $184,832.00$ \\
\hline 1995 & $14,527,817$ & 195 & 1,750 & $627,797.80$ & 413 & $306,033.00$ \\
\hline 1996 & $14,542,345$ & 203 & 2, 209 & $732,648.00$ & 993 & $766,000.20$ \\
\hline 1997 & $14,556,887$ & 210 & 2,492 & $657,888.00$ & 1,047 & $835,506.00$ \\
\hline 1998 & $14,571,444$ & 220 & 2,136 & $845,460.00$ & 1,019 & $851,884.00$ \\
\hline 1999 & $14,586,018$ & 220 & 2,745 & $673,764.00$ & 924 & $772,464.00$ \\
\hline 2000 & $14,600,602$ & 260 & 1,851 & $1,261,125.60$ & 925 & $913,900.00$ \\
\hline 2001 & 14,615,202 & 271 & 3,324 & $1,251,640.60$ & 1,017 & $1,047,306.60$ \\
\hline 2002 & $14,629,818$ & 271 & 3, 299 & $1,251,640.60$ & 812 & $836,197.60$ \\
\hline 2003 & $14,644,447$ & 325 & 2,559 & $1,164,345.00$ & 836 & $1,032,460.00$ \\
\hline 2004 & $14,659,092$ & 375 & 4, 079 & $2,141,475.00$ & 1,210 & $1,724,250.00$ \\
\hline Total & $160,446,972$ & & $28,376^{\mathrm{a}}$ & $10,347,806.00^{\mathrm{b}}$ & $9,452^{c}$ & $9,270,833.40^{\mathrm{d}}$ \\
\hline \multicolumn{7}{|c|}{$\begin{array}{l}\text { *- estimated national cattle population (Haruna and Muritala 2005) sourced from the } \\
\text { Federal Department of Livestock and Pest Control }\end{array}$} \\
\hline $\mathrm{a}+\mathrm{c}=$ & number & rattle wi & ondemned & er (partial + to & $\{37,828\}$ & \\
\hline
\end{tabular}




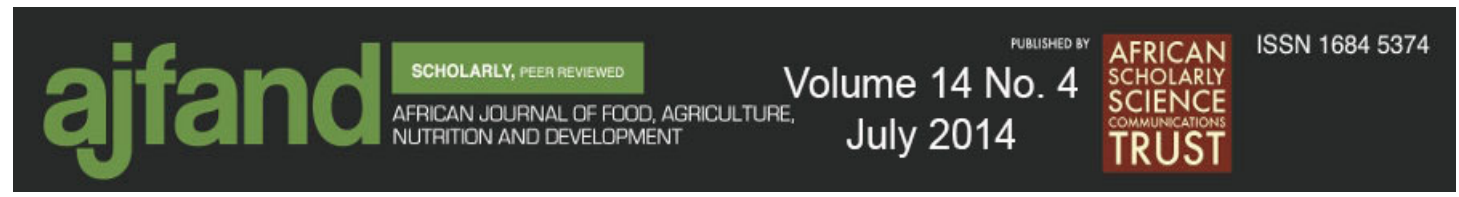

\section{REFERENCES}

1. Raji MA, Salami SO and JA Ameh Pathological conditions and lesions observed in slaughtered cattle in Zaria abattoir. J. Clin. Pathol. Forensic Med. 2010; 1(2): $9-12$.

2. Alawa CBI, Etukudo-Joseph I and JN Alawa A 6-year survey of pathological conditions of slaughtered animals at Zango abattoir in Zaria, Kaduna State, Nigeria. Trop. Anim. Hlth Prod. 2011; 43:127-131.

3. Walker SM, Makundi AE, Namuba FV, Kassuku AA, Keyyu J, Hoey EM, Prodohl P, Stothard JR and A Trudgett The distribution of Fasciola hepatica and Fasciola gigantica within southern Tanzania--constraints associated with the intermediate host. Parasitol. 2008; 135(4): 495-503.

4. Ogunrinade AF and BI Ogunrinade Economic importance of bovine fascioliasis in Nigeria. Trop. Anim. Hlth Prod. 1980; 12: 155 - 160.

5. Biu AA, Ahmed MI and SS Mshelia Economic assessment of losses due to parasitic diseases common at the Maiduguri abattoir, Nigeria. Afr. Sci. 2006; 7(3): 143-145.

6. Marques SMT and ML Scroferneker Fasciola hepatica infection in cattle and buffaloes in the state of Rio Grande do Sul, Brazil. Parasitol. Latinoam. 2003; 58: 169-172.

7. Mason C Fasciolosis associated with metabolic disease in a dairy herd, and its effects on health and productivity Cattle Prac. 2004; 12: 7-13.

8. Adedokun OA, Ayinmode AB and BO Fagbemi Seasonal prevalence of Fasciola gigantica infection among the sexes in Nigerian cattle. Vet. Res. 2008; 2(1): 12-14.

9. Esteban JG, Gonzalez C, Curtale F, Muñoz-Antoli C, Valero MA, Bargues MD, El Sayed M, El Wakeel A, Abdel-Wahab Y, Montresor A, Engels D, Savioli L and S Mas-Coma Hyperendemic fascioliasis associated with schistosomaisis in villages Nile delta of Egypt. Am. J. Trop. Med. Hyg. 2003; 69: 429-437.

10. National Bureau of Statistics (NBS) Federal Republic of Nigeria 2006 Population Census. Official Gazette (FGP 71/52007/2,500(OL24), Legal Notice on Publication of the Details of the Breakdown of the National and State Provisional Totals 2006 Census. 2006; http://www.nigerianstat.gov.ng/nbsapps/Connections/Pop2006.pdf (Accessed 21 July, 2011). 


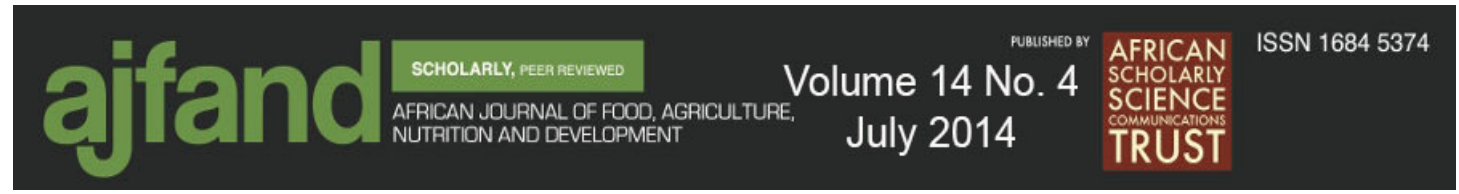

11. Filani MO Ibadan Region. Re-Charles Publications in conjunction with Connel Publications, Ibadan. 1994.

12. Ekwunife CA and CI Eneanya Fasciola gigantica in Onisha and environs. Anim. Res. Int. 2006; 3(2): 448 - 450.

13. Thrusfield M Veterinary Epidemiology $3^{\text {rd }}$ Ed, University of Edinburgh. Blackwell Sciences Publishing, Oxford. 2005: 626 pp.

14. Bamgboye EA A Companion of Medical Statistics. Ibipress \& Publishing Co., Ibadan. 2006.

15. Bekele $\mathbf{M}$, Tesfay $\mathbf{H}$ and $\mathbf{Y}$ Getachew Bovine Fasciolosis: Prevalence and its economic loss due to liver condemnation at Adwa Municipal Abattoir, North Ethiopia. Ethiopian J. Applied Sci. Technol. 2010; 1(1): 39-47.

16. Central Bank of Nigeria (CBN) Monthly Average Exchange Rates of the Naira (Naira Per Unit of Foreign Currency) - 2004; http://www.cenbank.org/rates/exrate.asp?year=2004 (Accessed 7 July 2011).

17. Ibironke AA A retrospective study of liver fluke disease in cattle based on abattoir data in Agege, Lagos, Nigeria. Afr. J. Food Agric. Nutri. Dev. 2010; 10: 2 .

18. Elkannah OS Preliminary Studies on Fascioliasis in cattle slaughtered at Jalingo Abattoir, Taraba State. Nig. J. Sci. Technol. Environ. Edu. 2010; 3(1): 143-147.

19. Haruna $\mathbf{S}$ and $\mathbf{N}$ Muritala Commodity Chain Analysis of cattle marketing in Nigeria; A case study of K.R.I.P Area Kano State. A report a report submitted to Agricultural Development in Nigeria (ADENI) Project/National Agricultural Extension and Research Liaison Services (NAERLS) Zaria. 2005; http://www.hubrural.org/pdf/nigeria_adeni_cattle_report.pdf (Accessed 21 August, 2011).

20. Ogunrinade AF, Okon AD and EF Fasanmi The prevalence of Bovine Fasciolosis in Nigeria: A year analysis of abattoir records. Bull. Anim. Hlth Prod. Afr. 1981; 29: 381-389.

21. Atta El, Mannan AM, Bushara HO and AM Majid Some Aspects of the Epidemiology of ovine Fasciolosis in Northern Gazira and Khartoum State. Sudan J. Vet. Res. 2001; 17: 35-40.

22. Schillhorn van Veen TW, Folaranmi DO, Usman $\mathbf{S}$ and $\mathbf{T}$ Ishaya Incidence of liver fluke infections (Fasciola gigantica and Dicrocoelium hospes) in ruminants in northern Nigeria. Trop. Anim. Hlth Prod. 1980; 12(2): 97-104. 


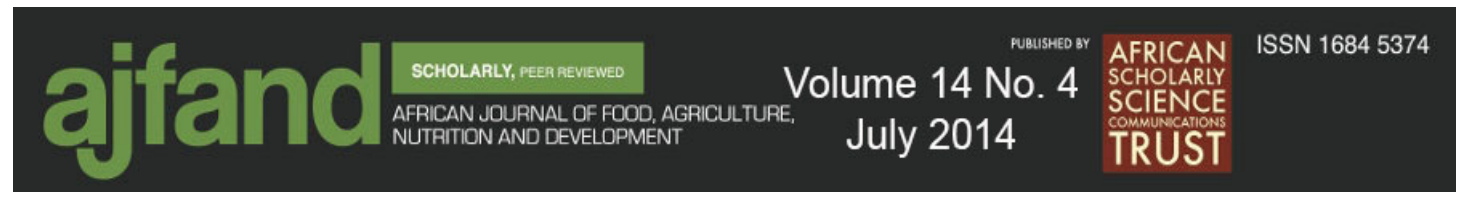

23. Babalola DA and TW Schillhorn van Veen Incidence of fascioliasis in cattle slaughtered in Buachi (Nigeria). Trop. Anim. Hlth Prod. 1976; 8(4): 243-247.

24. Better Business Initiative (BBI) Nigerian Economic Summit Group (NESG) Consultative Forum with Livestock Farmers in Northern Nigeria. 2004 http://www.pak-nigeria.org/pdfs/livestock_Forum_Summary.pdf (Accessed 6 September, 2011).

25. Index Mundi Nigeria Economic Profile 2004; http://www.indexmundi.com/en/facts/2004/nigeria/economy_profile.html (Accessed 6 September, 2011). 